Article

\title{
Effects of Propoxur Exposure on Insecticidal Susceptibility and Developmental Traits in Culex pipiens quinquefasciatus
}

\author{
Xiaolei Zhang, Samuel Karungu ${ }^{\oplus}$, Quanxin Cai, Zhiming Yuan * and Xiaomin Hu * \\ Key Laboratory of Special Pathogens and Biosafety, Wuhan Institute of Virology, Chinese Academy of Sciences, \\ Wuhan 430071, China \\ * Correspondence: yzm@wh.iov.cn (Z.Y.); huxm@wh.iov.cn (X.H.); Tel.: +86-27-8719-7242 (X.H.)
}

Received: 3 July 2019; Accepted: 5 September 2019; Published: 7 September 2019

check for updates

\begin{abstract}
Propoxur-sel strains of Culex pipiens quinquefasciatus were derived from a lab-bred strain following 16 generations of propoxur exposure under sublethal concentrations of $\mathrm{LC}_{25}$ (lethal concentration of $25 \%$ ) and $\mathrm{LC}_{50}$ (lethal concentration of $50 \%$ ), respectively. This resulted in resistance development in F16 with ratios of $8.8 \times$ and $6.3 \times$, respectively, compared with F0. The fecundity, longevity, sex ratio (F/M), and hatchability of the propoxur-exposed $C x$. quinquefasciatus adult survivors and their offspring were decreased, with no effect on the emergence ratio and pupa survival rate. In addition, the intrinsic rates of increase $(r)$, the net reproduction $\left(R_{0}\right)$, and the finite rate of increase $(\lambda)$ of the $C x$. quinquefasciatus offspring generations were also decreased significantly compared to F0. Correspondingly, the mean generation time (T) and the population double time (DT) in propoxur-sels were increased. Enhanced activities of cytochrome P450 monooxygenase and esterase were also observed in propoxur-sels, indicating that a detoxification mechanism might be responsible for resistance development in Cx. quinquefasciatus. Except for the three genes cyp4d42v1, cyp4c52v1, and cyp6aa9 which displayed a coincidence in some degree in different treatments, induction by different doses of propoxur and constitutive expression in different generations of propoxur-sel strains resulted in an inconsistent identification of the P450 genes probably related with resistance.
\end{abstract}

Keywords: Culex pipiens quinquefasciatus; propoxur; sublethal and lethal exposure; resistance; developmental traits

\section{Introduction}

Culex pipiens quinquefasciatus is a common nuisance biting insect around the world. It is also a primary vector of many human ailments (e.g., filariasis, encephalitis, West Nile and Zika virus-infecting diseases) that pose a major global health threat [1-5]. Vector control is an effective preventive approach against mosquito biting and major vector-borne diseases, since this intervention could reduce human-vector contact and vector survival; thus, the transmission of these diseases can be suppressed and even halted [6-8]. Therefore, insecticides have been massively used and expanded for mosquito control $[7,9]$.

The concentrations of insecticide spread into the environment are usually varied [10] and switch from lethal (when initially applied) to sublethal (with the degradation over time). On one hand, the breeding sites of the immature stages of mosquitos (larvae and pupae) are always aquatic environments, e.g., puddles, ditches, and rice fields [11], which could be contaminated by agrochemical pesticides and pose an opportunity for chronic and/or subchronic exposure [12]. On the other hand, due to limited exposure time and spatial range and to delayed onset of killing, the adult mosquito populations could also experience exposure to sublethal concentrations of insecticides [13]. Thus, 
mosquitoes are likely to be exposed to sublethal doses during the control application of pesticides, which could affect mosquito populations directly or indirectly $[8,13,14]$. Previous studies have shown that continued exposure to sublethal doses can lead to the emergence/development of insecticide-resistant populations, as well as sublethal effects on insect physiology and behavior $[8,15,16]$.

The mechanism of resistance could be complicated and caused by a variety of genetic modifications related with metabolic detoxification and target site insensitivity [17]. A correlation has also been established in previous studies between the degree of resistance and enzyme activity expressed in mosquito, including esterase, glutathione S-transferase (GST), and cytochrome P450 monooxygenase [7]. In addition, structural modification of acetylcholinesterase (AChE), encoded by the ace-1 gene, which is a key enzyme promoting nerve signal transmission in both vertebrates and invertebrates, could make the mosquito insensitive to organophosphate and carbamate pesticides [18]. Moreover, agrochemical residues may affect the microbiome of mosquitoes and are commonly associated with some fitness traits of the dipteral insects $[19,20]$.

Carbamate insecticides have been recommended for mosquito control due to their lower dermal toxicity and less unfavorable neurotoxic properties than organochlorine insecticides [21]. Propoxur, a widely used broad-spectrum carbamate insecticide, was introduced as an insecticide in 1959 [22,23]. Because of its fast killing and long residual effect, it has been widely used in hygienic, store house, and agricultural insect pest control with tremendous success. For instance, it was developed as cockroach poison and has been used against mosquitoes within long-lasting insecticidal nets (LLINs) and in- and outdoor residual spraying (ORS and IRS) programs. Consequently, it has been frequently detected in agricultural and aquatic environments due to its massive use [24]. However, the influence of short- and long-term exposure to sublethal propoxur on multiple traits associated with the life cycle of these insects remains unclear.

In this study, the susceptibility shift of $C x$. quinquefasciatus to propoxur and other insecticides was assessed after being subjected to short- and long-term exposure to sublethal doses of propoxur. In addition, the resistance mechanism and the transgenerational effects on Cx. quinquefasciatus, especially at the multigenerational level, were analyzed. This study provides valuable information for the management of propoxur resistance and lays a foundation for the development of effective integrated pest management programs.

\section{Materials and Methods}

\subsection{Mosquitoes}

A sensitive Cx. quinquefasciatus colony (set as F0) was established from a laboratory-reared colony more than 10 years ago without exposure to any insecticide. The larvae were reared in enamel pans filled with dechlorinated tap water and fed with a mixture of yeast powder and wheat mill. The pupae were removed from the pans every day and placed in cages for emergence. The male adults were fed on $10 \%$ sucrose solution, while the females were fed with blood from mice. All larvae and adults were held at $27 \pm 1{ }^{\circ} \mathrm{C}$ and a photoperiod of 12:12 h (light-dark).

\subsection{Insecticides}

The insecticide propoxur (97\%) was supplied by Jiangsu Changlong Agrochemical Co., Ltd Jiangsu, China. Etofenprox (95\%), nitenpyram (96\%), abamectin (97\%), chlorpyrifos (98\%), and deltamethrin (95\%) were supplied by Hubei Kangbaotai Fine-Chemicals Co., Ltd. Wuhan, China. The spinetoram (60 g/L SC) was supplied by the Dow AgroSciences Company. Propoxur, etofenprox, abamectin, chlorpyrifos, and deltamethrin were dissolved in acetone, and nitenpyram and spinetoram were dissolved in water. Active ingredient $(0.1 \mathrm{~g})$ was dissolved in $2 \mathrm{~mL}$ acetone, and $50 \mathrm{~g} / \mathrm{L}$ mother liquor was obtained. Then, it was diluted to $0.1 \mathrm{mg} / \mathrm{L}, 1 \mathrm{mg} / \mathrm{L}, 10 \mathrm{mg} / \mathrm{L}$, and $100 \mathrm{mg} / \mathrm{L}$ with water. The same volume of solvent without insecticide was added to each control group during the bioassay. 


\subsection{Bioassay}

Bioassays were carried out according to the standard method recommended by the World Health Organization [6]. Twenty third-instar larvae were transferred into $100 \mathrm{~mL}$ of distilled water in a $200 \mathrm{~mL}$ plastic cup. Three replicates for each dose and nine doses in total for each insecticide were set, and the controls were treated with dechlorinated tap water. All treatments were maintained at a temperature of $27 \pm 1{ }^{\circ} \mathrm{C}$ and $40-50 \%$ relative humidity with a $12 \mathrm{~h}$ light/ $12 \mathrm{~h}$ dark photoperiod. Mortality was assessed after exposure to insecticides for $24 \mathrm{~h}$.

\subsection{Resistance Selection and Sublethal Effects of Short-Term Exposure to Propoxur}

The $\mathrm{LC}_{25}$ (lethal concentration of $25 \%$ ) and $\mathrm{LC}_{50}$ (lethal concentration of $50 \%$ ) concentrations of propoxur were first determined using the $25 \%$ and $50 \%$ mortality rates, respectively, of the susceptible strain F0 (not treated by propoxur) assessed after exposure for $24 \mathrm{~h}$. For resistance selection, about 300-2000 third-instar larvae were treated with the $\mathrm{LC}_{25}$ and $\mathrm{LC}_{50}$ concentrations of propoxur every day to pupa stage, and the mortality rate of the larvae was maintained in the range $20-90 \%$ in each generation from F1 to F16. The colonies of F1-F16 were named according to continuous selection by propoxur from generations 1 to 16. In addition, the following data were also observed and recorded daily: the number of eggs and hatching larvae, the number of surviving larvae and pupa, the number of female adults and male adults, and the developmental time of eggs, larvae, pupae, female adults, and male adults.

\subsection{Assessment of the Transgenerational Effects of Propoxur Exposure}

The F1, F5, F10, and F15 colonies of the propoxur-sel strains were developed from the eggs of F0, F4, F9, and F14 treated with $\mathrm{LC}_{25}$ and $\mathrm{LC}_{50}$ of propoxur and collected on the same day, and they were transferred to an enamel basin with $3000 \mathrm{~mL}$ dechlorinated tap water. The first-instar larvae were collected randomly from the newly hatched colonies, individually transferred to an enamel basin with $1000 \mathrm{~mL}$ dechlorinated tap water, and reared until to the fourth and final instar. The pupae were collected in a $200 \mathrm{~mL}$ beaker with $150 \mathrm{~mL}$ distilled water. The adult males and females were put into a cage and were maintained with $10 \%$ sucrose solution. After blood feeding on mice for $72 \mathrm{~h}$, the female adults were transferred into another cage and maintained with $10 \%$ sucrose solution. Volumes of $150 \mathrm{~mL}$ of distilled water in $200 \mathrm{~mL}$ plastic cups were put in the cage for their oviposition. The following data were observed and recorded daily: the number of eggs and hatching larvae, the number of surviving larvae and pupae, the number of female adults and male adults, and the developmental time of eggs, larvae, pupae, female adults, and male adults.

\subsection{Detection of Mutation in AChE Encoding Gene Ace-1}

Total RNA was isolated from the fourth-instar larvae of $C x$. quinquefasciatus using a TRIzol ${ }^{\mathrm{TM}}$ Reagent (Thermo Fisher Scientific Life Technologies Corporation, Carlsbad, CA, USA). cDNA synthesis was performed using the GoScriptTM Reverse Transcription System (Promega, Madison, WI, USA). The ace-1 genes of the surviving larvae after exposure to propoxur were amplified with the primers described in [25]. The purified PCR fragments were used for sequencing and comparison with those of the wild population.

\subsection{Enzyme Activity Assays}

To determine the activities of esterase, glutathione $S$-transferase (GST), and cytochrome P450 monooxygenase (P450) of $C x$. quinquefasciatus, 60 larvae from each generation were homogenized on ice in $1 \mathrm{~mL}$ of $0.1 \mathrm{M}$ sodium phosphate buffer ( $\mathrm{pH} 7.0$ containing $1 \mathrm{mM}$ EDTA, $1 \mathrm{mM}$ dithiothreitol (DTT), $1 \mathrm{mM}$ phenylthiourea, $1 \mathrm{mM}$ PMSF (phenylmethanesulfonyl fluoride), and 20\% glycerol) [26]. The homogenate was then centrifuged at $15,000 \times g$ for $20 \mathrm{~min}$ at $4{ }^{\circ} \mathrm{C}$. The supernatants were harvested 
as the mosquito crude extractions and stored at $-80{ }^{\circ} \mathrm{C}$ until use. The protein concentrations were determined using the Bio-Rad Protein Assay Kit, Bio-Rad Laboratories, Hercules, CA, USA.

The esterase activity was determined as previously described with minor modifications. In brief, $200 \mu \mathrm{L}$ of the assayed mixture which contained $2 \mu \mathrm{L}$ of $\alpha$-naphthyl acetate substrate $(0.2 \mathrm{mM})$ and $10 \mu \mathrm{L}$ of diluted mosquito crude extraction in sodium phosphate buffer $(0.2 \mathrm{M}, \mathrm{pH} 7.0)$ was pipetted into a 96 -well plate and incubated at $37^{\circ} \mathrm{C}$ for $15 \mathrm{~min}$. The reaction was stopped by the addition of the colorimetric reagent FAST Blue $B$, and the absorbance was measured at OD $450 \mathrm{~nm}$.

The glutathione $S$-transferase (GST) activity was assessed using 1-chloro-2, 4-dinitrobenzene $(\mathrm{CDNB})$ as the substrate as previously described. The $200 \mu \mathrm{L}$ reaction mixture consisted of $6 \mu \mathrm{L}$ of $30 \mathrm{mM}$ CDNB substrate solution, $6 \mu \mathrm{L}$ of $30 \mathrm{mM} \mathrm{GSH}$, and $10 \mu \mathrm{L}$ of the diluted mosquito crude extraction in sodium phosphate buffer $(0.1 \mathrm{M}, \mathrm{pH}$ 7.0). The absorbance was measured using an ultraviolet spectrophotometer at $340 \mathrm{~nm}$ for $5 \mathrm{~min}$ with a read interval of $30 \mathrm{~s}$.

The cytochrome P450 monooxygenase (P450) activity was determined using p-nitroanisole (p-NA) as the substrate as previously described [27]. Volumes of $100 \mu \mathrm{L}$ of $2 \mathrm{mM}$ p-NA, $10 \mu \mathrm{L}$ of $9.6 \mathrm{mM}$ $\mathrm{NADPH}$, and $90 \mu \mathrm{L}$ of the diluted mosquito crude extraction in sodium phosphate buffer $(0.1 \mathrm{M}$, $\mathrm{pH}$ 7.0) were mixed and then pipetted into a 96-well plate. After incubation at $34^{\circ} \mathrm{C}$ for $30 \mathrm{~min}$ with shaking, the absorbance was recorded using a microplate reader (Bio-Rad) at $405 \mathrm{~nm}$.

\subsection{Quantitative Real-Time PCR ( $q R T-P C R)$}

Total RNA was isolated from the fourth-instar larvae of $C x$. quinquefasciatus using a TRIzol ${ }^{\mathrm{TM}}$ Reagent (Thermo Fisher Scientific Life Technologies Corporation, Carlsbad, CA, USA). cDNA synthesis was performed using the GoScriptTM Reverse Transcription System (Promega, Madison, USA). The induction of P450 gene expression was performed with the SYBR Green Master Mix Kit on a MyiQ2 real-time PCR system (Bio-Rad, California, USA). The qRT-PCR was in a $25 \mu \mathrm{L}$ final reaction volume containing $1 \times$ SYBR Green Master Mix, $1 \mu \mathrm{L}$ of cDNA, and a P450 gene-specific primer pair, designed according to each of the P450 gene sequences as described previously [28-30] at a final concentration of 3-5 $\mu \mathrm{M}$. RT-qPCR was performed with the following cycling regime: initial incubation at $95^{\circ} \mathrm{C}$ for $5 \mathrm{~min}$, followed by 40 cycles of $95^{\circ} \mathrm{C}$ for $5 \mathrm{~s}$ and $55^{\circ} \mathrm{C}$ for $10 \mathrm{~s}$. The $18 \mathrm{~s}$ ribosome RNA gene was used to normalize the expression of target genes. Relative expression levels for the $\mathrm{P} 450$ genes were calculated by the $2^{-\Delta \Delta C T}$ method [31], in which $\Delta \Delta C T=(C T$, Target $-\mathrm{CT}, 18 \mathrm{~S}$ rRNA)Treated $-(C T$, Target - CT, 18S rRNA)Control.

\subsection{Statistical Analysis}

The $\mathrm{LC}_{50}$ values with $95 \%$ confidence interval, slopes with standard error (SE), and chi-square value $\left(\chi^{2}\right)$ with degree of freedom (df) were calculated using a regression model based on a probit transformation of mortalities and a logarithmic transformation of concentrations tested, i.e., a log-probit model by Polo Plus software. The means and standard errors (SE) of the mosquito population parameters of the developmental traits were analyzed by using TWOSEX-MSChart software as previously described [32-36]. The egg hatchability is the percent of eggs that hatched (the number of hatching larvae/the number of eggs). The fecundity (the mean number of eggs laid per adult female of $C x$. quinquefasciatus), longevity, sex ratio ( $\mathrm{F}$ (female)/M (male)), population doubling time (DT), and the population parameters (r, the intrinsic rate of increase; $\lambda$, the finite rate of increase; $R_{0}$, the net reproductive rate; $\mathrm{T}$, the mean generation time) were calculated accordingly.

$$
\begin{gathered}
\mathrm{T}=\frac{\ln R_{0}}{r} \\
R_{0}=\sum_{x=0}^{\infty} l_{x} m_{x}
\end{gathered}
$$




$$
\begin{gathered}
\mathrm{DT}=\frac{\ln 2}{r} \\
\lambda=e^{r} \\
\sum_{x=0}^{\infty} * e^{-r(x+1)} l_{x} m_{x}=1
\end{gathered}
$$

Here, $m_{x}$ is the average egg number laid per surviving $C x$. quinquefasciatus during the age interval $x ; l_{x}$ is the probability that a newborn will survive from age 0 to $x$. The mean generation time $(T)$ is the length of time of an insect population increasing to $R_{0}$-fold of its initial size (i.e., $e^{r T}=R_{0}$ or $\lambda^{T}=R_{0}$ ) at the stable age structure distribution. The doubling time (DT) is the length of time that an insect population needs to double its initial size (i.e., $\mathrm{e}^{\mathrm{rD}}=2$ or $\lambda^{\mathrm{D}}=2$ ) after the population reaches the stable age structure distribution. The parameters $r$ and $\lambda$ reveal the effect of insect reproductive ages on the population growth rate at the stable age structure distribution. The parameter $R_{0}$ represents the total offspring number of an average individual.

TWOSEX-MSChart for the age-stage, two-sex life table analysis was used to compare the population parameters $\left(r, \lambda, R_{0}\right.$, and $\left.T\right)$, fecundity, longevity, proportions of male and female $(F / M)$, and population doubling time (DT) differences among treatments by the Tukey Kramer procedure. The data of enzyme activity and expression of P450 were analyzed by ANOVA followed by Duncan's test. $p<0.05$ was thought to be statistically significant. The statistical analyses were performed using IBM SPSS Statistics software (v19). However, significant overexpression was determined using a cut-off value of a $\geq 2$-fold change in expression [29].

\section{Results}

\subsection{Resistance Development After Selection with Sublethal Exposure to Propoxur}

The propoxur-sel strains of $C x$. quinquefasciatus were derived in the laboratory from a lab-feeding strain following 16 generations of propoxur exposure (Figure 1). F16 developed 8.8-fold resistance to propoxur in $\mathrm{LC}_{25}$ selection with an $\mathrm{LC}_{50}$ value of $2.55 \mathrm{mg} \mathrm{L}^{-1}$ and 6.3 -fold resistance in $\mathrm{LC}_{50}$ selection with an $\mathrm{LC}_{50}$ of $1.82 \mathrm{mg} \mathrm{L}^{-1}$ compared with the initial $\mathrm{LC}_{50}$ of $0.29 \mathrm{mg} \mathrm{L}^{-1}$ in the susceptible strain (F0), respectively (Figure 1). However, compared with the susceptible strain, the propoxur-sels showed no significant cross-resistance to the other six tested insecticides (etofenprox, deltamethrin, nitenpyram, abamectin, chlorpyrifos, and spinetoram; Figure 2).

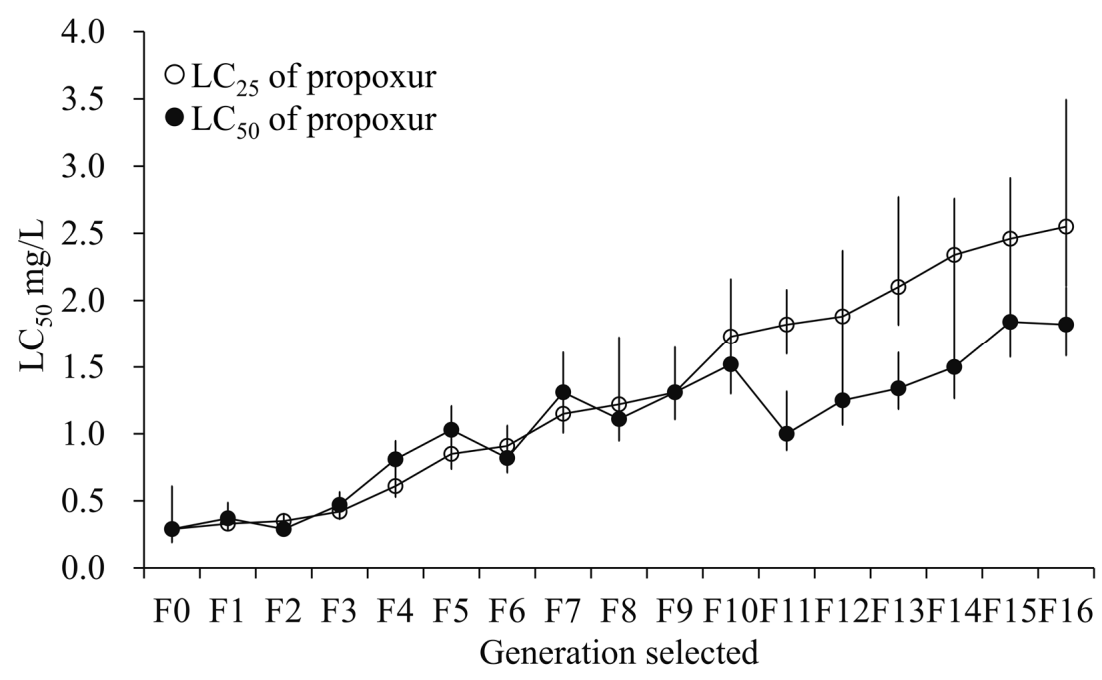

Figure 1. Resistance development of Culex pipiens quinquefasciatus after selection with $\mathrm{LC}_{25}$ (lethal concentration of $25 \%$ ) (open circles) and $\mathrm{LC}_{50}$ (lethal concentration of $50 \%$ ) (shaded circles) levels of propoxur. 

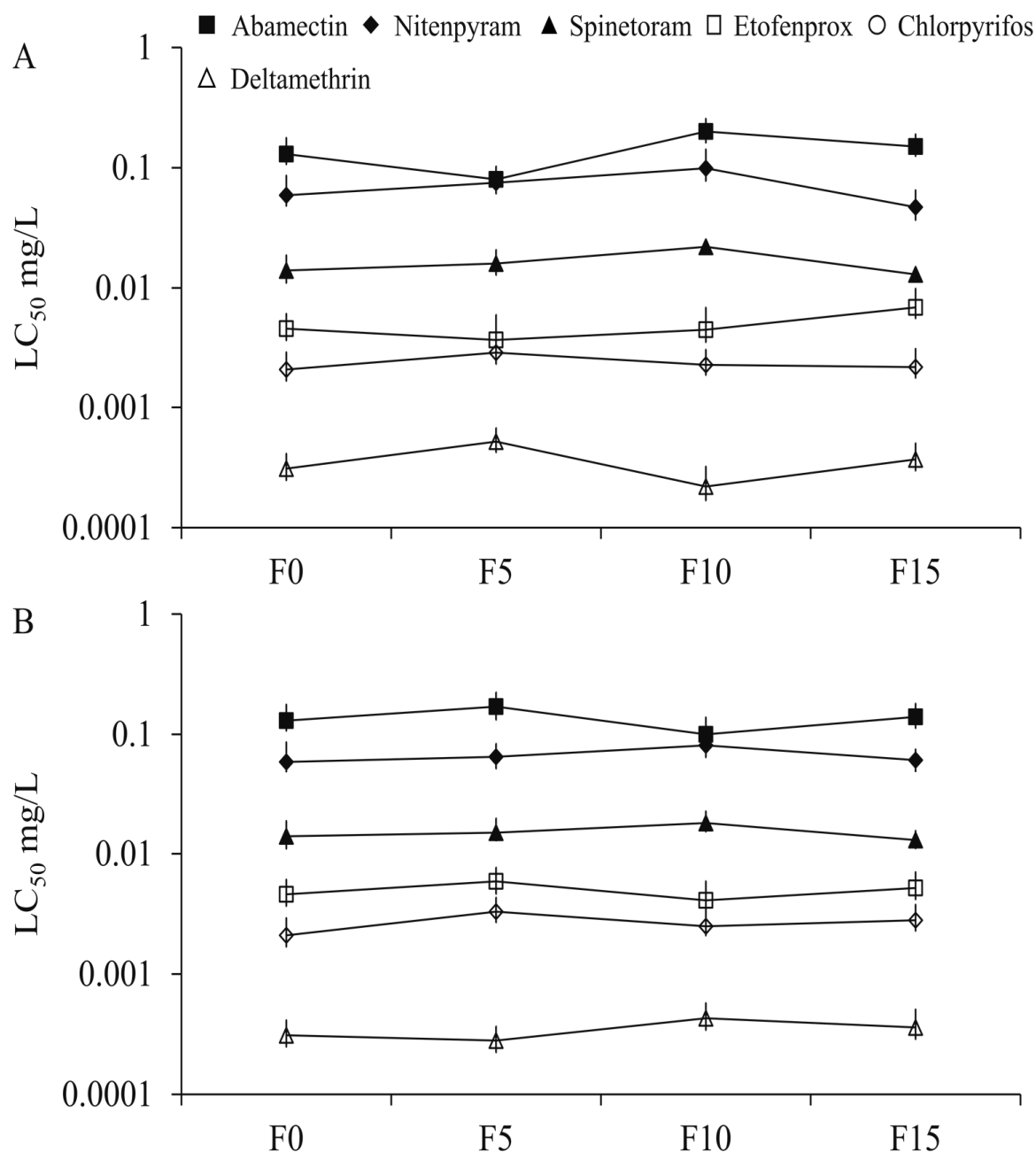

Figure 2. Cross-resistance to tested insecticides in $C x$. quinquefasciatus treated with $\mathrm{LC}_{25}(\mathbf{A})$ and $\mathrm{LC}_{50}$ (B) levels of propoxur.

3.2. Effects on the Developmental Traits of Adults, Pupae, and Eggs of Parental Cx. Quinquefasciatus after Sublethal and Lethal Exposure to Propoxur

Both the $\mathrm{LC}_{25}$ and $\mathrm{LC}_{50}$ propoxur treatments obviously affected the mortality rates: the former resulted in mortality rates of $15.6-57.3 \%$ in F1-F16 compared with $8.2 \%$ in F0, and the latter as high as ca. $60.9-97.9 \%$ in F1-F16 compared with 5.0\% in F0. In addition, the sex ratios in the adult survivors of propoxur-exposed $C x$. quinquefasciatus colonies were significantly affected, displaying female/male ratios $(\mathrm{F} / \mathrm{M})$ of 1:3-1:6 and 1:4-1:11 in the $\mathrm{LC}_{25}$ and $\mathrm{LC}_{50}$ treatments, respectively, compared to 1:1 in F0 without the treatment of propoxur (Table 1). Moreover, ca. $6.3-16.2 \%$ and $5.3-15.5 \%$ reductions in egg hatching of the adult survivors were observed in the $\mathrm{LC}_{25}$ and $\mathrm{LC}_{50}$ propoxur treatments, respectively. However, the emergence ratio and pupa survival rate were not affected (Table 1).

\subsection{Transgenerational Impact of Propoxur on Demographic Parameters and Developmental Traits}

The differences in demographic parameters and developmental traits between progeny of the untreated susceptible strain (F0) and propoxur-sel strains (F1, F5, F10, and F15) with the LC 25 and $\mathrm{LC}_{50}$ propoxur treatments are shown in Tables 2 and 3. The longevities and fecundities of propoxur-sel strains decreased nearly $14.3-26.2 \%$ and $4.3-12.2 \%$, respectively, compared with that of F0. The sex ratio $(\mathrm{F} / \mathrm{M})$ decreased from 1:1 in F0 to 1:2 in F1 and F5 and 1:3 in F10 and F15 in propoxur-sel strains. Correspondingly, the population doubling time (DT) in propoxur-sel strains increased by $29.2-82.1 \%$ compared to that in F0. In addition, the intrinsic rates of increase (r) reduced from 0.16 in F0 to 0.10-0.13 
in propoxur-sel strains, and the net reproduction rates $\left(R_{0}\right)$ were also significantly decreased to only $33.4-58.9 \%$ that of F0. The finite rate of increase $(\lambda)$ was decreased by $4.2-7.6 \%$ compared with that of F0 as well. Meanwhile, the mean generation time (T) was significantly prolonged in propoxur-sel strains compared to that in F0.

Table 1. Effects of prolonged sublethal and lethal exposure to propoxur of $C x$. quinquefasciatus.

\begin{tabular}{|c|c|c|c|c|c|c|c|c|}
\hline \multirow{2}{*}{ G } & \multicolumn{4}{|c|}{ Cx. quinquefasciatus Treated with $\mathrm{LC}_{25}$ of Propoxur } & \multicolumn{4}{|c|}{ Cx. quinquefasciatus Treated with $\mathrm{LC}_{50}$ of Propoxur } \\
\hline & $\mathbf{F} / \mathbf{M}$ & $\mathbf{H} \%$ & $\mathrm{Sp} \%$ & $\mathrm{Er} \%$ & $\mathbf{F} / \mathbf{M}$ & $\mathbf{H} \%$ & $\mathrm{Sp} \%$ & Er\% \\
\hline F0 & $1: 1 \mathrm{a}$ & $92.6 \pm 2.6 \mathrm{a}$ & $93.8 \pm 1.2 \mathrm{a}$ & $92.2 \pm 1.2 \mathrm{a}$ & $1: 1 \mathrm{a}$ & $93.6 \pm 0.1 \mathrm{a}$ & $98.7 \pm 0.4 \mathrm{a}$ & $98.7 \pm 0.4 \mathrm{a}$ \\
\hline F1 & $1: 5 \mathrm{~b}$ & $91.0 \pm 0.8 \mathrm{a}$ & $92.6 \pm 1.2 \mathrm{a}$ & $89.0 \pm 1.3 \mathrm{a}$ & $1: 8 \mathrm{~b}$ & $87.3 \pm 1.2 \mathrm{~b}$ & $95.7 \pm 2.1 \mathrm{a}$ & $93.8 \pm 3.4 \mathrm{a}$ \\
\hline $\mathrm{F} 2$ & $1: 6 \mathrm{~b}$ & $87.3 \pm 1.8 \mathrm{~b}$ & $93.6 \pm 0.9 \mathrm{a}$ & $91.1 \pm 1.2 \mathrm{a}$ & $1: 9 \mathrm{~b}$ & $85.6 \pm 0.4 b$ & $96.3 \pm 3.7 \mathrm{a}$ & $92.6 \pm 7.4 \mathrm{a}$ \\
\hline F3 & $1: 4 \mathrm{~b}$ & $85.9 \pm 2.4 b$ & $94.6 \pm 0.8 \mathrm{a}$ & $90.9 \pm 0.6 \mathrm{a}$ & $1: 11 \mathrm{~b}$ & $83.8 \pm 2.8 b$ & $90.8 \pm 1.4 b$ & $90.2 \pm 1.0 \mathrm{a}$ \\
\hline $\mathrm{F} 4$ & $1: 4 \mathrm{~b}$ & $81.3 \pm 0.2 b$ & $95.0 \pm 1.3 \mathrm{a}$ & $92.1 \pm 1.1 \mathrm{a}$ & $1: 6 \mathrm{~b}$ & $82.3 \pm 1.0 \mathrm{~b}$ & $98.3 \pm 0.9 a$ & $97.5 \pm 1.3 a$ \\
\hline F5 & $1: 3 \mathrm{~b}$ & $83.8 \pm 3.1 b$ & $94.3 \pm 2.1 \mathrm{a}$ & $90.8 \pm 1.3 \mathrm{a}$ & $1: 6 b$ & $84.7 \pm 1.1 b$ & $96.9 \pm 3.1 \mathrm{a}$ & $92.1 \pm 4.2 \mathrm{a}$ \\
\hline F6 & $1: 4 \mathrm{~b}$ & $84.1 \pm 2.3 b$ & $94.1 \pm 0.9 \mathrm{a}$ & $90.5 \pm 1.4 \mathrm{a}$ & $1: 4 b$ & $82.4 \pm 5.3 b$ & $96.4 \pm 0.2 \mathrm{a}$ & $95.2 \pm 1.1 \mathrm{a}$ \\
\hline F7 & $1: 5 b$ & $84.9 \pm 0.8 b$ & $94.8 \pm 1.7 \mathrm{a}$ & $92.9 \pm 2.1 \mathrm{a}$ & $1: 7 \mathrm{~b}$ & $81.6 \pm 0.8 b$ & $94.6 \pm 2.8 \mathrm{a}$ & $94.6 \pm 2.8 \mathrm{a}$ \\
\hline F8 & $1: 5 \mathrm{~b}$ & $80.6 \pm 0.6 b$ & $91.2 \pm 1.8 \mathrm{a}$ & $88.9 \pm 2.3 \mathrm{a}$ & $1: 8 \mathrm{~b}$ & $86.3 \pm 2.4 b$ & $97.8 \pm 1.2 \mathrm{a}$ & $95.1 \pm 1.3 \mathrm{a}$ \\
\hline F9 & $1: 6 \mathrm{~b}$ & $81.2 \pm 2.0 b$ & $93.0 \pm 0.6 \mathrm{a}$ & $89.8 \pm 0.6 \mathrm{a}$ & $1: 6 b$ & $80.1 \pm 1.8 b$ & $97.2 \pm 1.8 \mathrm{a}$ & $95.1 \pm 3.9 \mathrm{a}$ \\
\hline F10 & $1: 6 \mathrm{~b}$ & $77.1 \pm 1.7 \mathrm{~b}$ & $93.1 \pm 1.3 \mathrm{a}$ & $88.0 \pm 2.4 \mathrm{a}$ & $1: 6 \mathrm{~b}$ & $82.1 \pm 0.2 b$ & $97.4 \pm 1.6 \mathrm{a}$ & $94.2 \pm 0.7 \mathrm{a}$ \\
\hline F11 & $1: 5 \mathrm{~b}$ & $79.6 \pm 1.6 b$ & $93.9 \pm 1.7 \mathrm{a}$ & $87.9 \pm 1.1 \mathrm{a}$ & $1: 9 \mathrm{~b}$ & $84.5 \pm 2.8 b$ & $100.0 \pm 0.0 \mathrm{a}$ & $87.1 \pm 11.4 \mathrm{a}$ \\
\hline F12 & $1: 5 b$ & $81.4 \pm 2.3 b$ & $94.8 \pm 1.2 \mathrm{a}$ & $89.7 \pm 2.5 \mathrm{a}$ & $1: 5 \mathrm{~b}$ & $84.9 \pm 0.6 b$ & $94.0 \pm 1.1 \mathrm{a}$ & $89.2 \pm 2.1 \mathrm{a}$ \\
\hline F13 & $1: 4 \mathrm{~b}$ & $81.7 \pm 1.4 b$ & $94.3 \pm 2.3 \mathrm{a}$ & $90.5 \pm 2.0 \mathrm{a}$ & $1: 5 \mathrm{~b}$ & $79.8 \pm 2.8 b$ & $97.8 \pm 2.2 \mathrm{a}$ & $97.8 \pm 2.2 \mathrm{a}$ \\
\hline F14 & $1: 3 \mathrm{~b}$ & $82.8 \pm 1.0 \mathrm{~b}$ & $93.0 \pm 0.6 \mathrm{a}$ & $90.1 \pm 0.4 \mathrm{a}$ & $1: 10 \mathrm{~b}$ & $82.9 \pm 1.3 b$ & $98.2 \pm 1.8 \mathrm{a}$ & $96.7 \pm 1.7 \mathrm{a}$ \\
\hline F15 & $1: 3 \mathrm{~b}$ & $82.1 \pm 1.2 \mathrm{~b}$ & $94.1 \pm 1.5 \mathrm{a}$ & $90.8 \pm 1.7 \mathrm{a}$ & $1: 4 \mathrm{~b}$ & $77.4 \pm 3.2 b$ & $94.3 \pm 3.2 \mathrm{a}$ & $87.7 \pm 2.8 \mathrm{a}$ \\
\hline F16 & $1: 5 \mathrm{~b}$ & $84.8 \pm 1.5 \mathrm{~b}$ & $94.3 \pm 0.3 \mathrm{a}$ & $90.8 \pm 0.8 \mathrm{a}$ & $1: 4 \mathrm{~b}$ & $82.2 \pm 2.2 \mathrm{~b}$ & $94.8 \pm 2.6 \mathrm{a}$ & $89.3 \pm 1.8 \mathrm{a}$ \\
\hline
\end{tabular}

G: generation, F/M: proportion of males and females, H: egg hatchability, Sp: survival rate of pupae (the number of surviving pupae on the first day/number of pupation), Er: emergence rate. The values are given as mean \pm SE. The effects of prolonged sublethal and lethal exposure were analyzed by ANOVA followed by Duncan's test using IBM SPSS Statistics 19. a: No significant difference compared with F0 at the $p=0.05$ level. b: Significant difference compared with F0 at the $p=0.05$ level.

Table 2. Transgenerational effects of exposure to propoxur to doubling time, fecundity, longevity, and sex ratio of $C x$. quinquefasciatus.

\begin{tabular}{ccccccccc}
\hline \multirow{2}{*}{ G } & \multicolumn{2}{c}{ Cx. quinquefasciatus Treated with LC $_{25}$ of Propoxur } & \multicolumn{2}{c}{ C $x$. quinquefasciatus Treated with LC 50 of Propoxur } \\
\cline { 2 - 10 } & DT (d) & $\begin{array}{c}\text { Fecundity } \\
\text { (eggs/o) }\end{array}$ & Longevity (d) & F/M & DT (d) & $\begin{array}{c}\text { Fecundity } \\
\text { (eggs/9) }\end{array}$ & Longevity (d) & F/M \\
\hline F0 & $4.25 \pm 0.11 \mathrm{a}$ & $70.22 \pm 2.84 \mathrm{E}-14 \mathrm{a}$ & $39.49 \pm 1.31 \mathrm{a}$ & $1: 1 \mathrm{a}$ & $4.25 \pm 0.11 \mathrm{a}$ & $70.22 \pm 2.84 \mathrm{E}-14 \mathrm{a}$ & $39.49 \pm 1.31 \mathrm{a}$ & $1: 1 \mathrm{a}$ \\
F1 & $5.49 \pm 0.25 \mathrm{~b}$ & $70.33 \pm 1.42 \mathrm{E}-14 \mathrm{a}$ & $31.48 \pm 1.32 \mathrm{~b}$ & $1: 2 \mathrm{~b}$ & $6.45 \pm 0.35 \mathrm{~b}$ & $63.44 \pm 4.26 \mathrm{E}-14 \mathrm{~b}$ & $31.18 \pm 1.36 \mathrm{~b}$ & $1: 2 \mathrm{~b}$ \\
F5 & $6.08 \pm 0.32 \mathrm{~b}$ & $66.77 \pm 2.84 \mathrm{E}-14 \mathrm{~b}$ & $33.83 \pm 1.42 \mathrm{~b}$ & $1: 2 \mathrm{~b}$ & $6.78 \pm 0.52 \mathrm{~b}$ & $64.80 \pm 3.89 \mathrm{E}-14 \mathrm{~b}$ & $33.11 \pm 1.50 \mathrm{~b}$ & $1: 3 \mathrm{~b}$ \\
F10 & $6.79 \pm 0.43 \mathrm{~b}$ & $64.35 \pm 1.42 \mathrm{E}-14 \mathrm{~b}$ & $31.55 \pm 1.31 \mathrm{~b}$ & $1: 3 \mathrm{~b}$ & $7.04 \pm 0.56 \mathrm{~b}$ & $61.66 \pm 1.42 \mathrm{E}-14 \mathrm{~b}$ & $31.79 \pm 1.43 \mathrm{~b}$ & $1: 3 \mathrm{~b}$ \\
F15 & $6.46 \pm 0.41 \mathrm{~b}$ & $67.19 \pm 2.84 \mathrm{E}-14 \mathrm{~b}$ & $29.99 \pm 1.23 \mathrm{~b}$ & $1: 3 \mathrm{~b}$ & $7.74 \pm 0.71 \mathrm{~b}$ & $66.96 \pm 1.42 \mathrm{E}-14 \mathrm{~b}$ & $29.13 \pm 1.54 \mathrm{~b}$ & $1: 3 \mathrm{~b}$ \\
\hline
\end{tabular}

DT: Population doubling time. The values are given as mean \pm SE. a: No significant difference compared with F0 at the $p=0.05$ level. b: Significant difference compared with F0 at the $p=0.05$ level.

Table 3. Transgenerational effects of propoxur exposure on demographic parameters of $C x$. quinquefasciatus.

\begin{tabular}{|c|c|c|c|c|c|c|c|c|}
\hline \multirow{2}{*}{ G } & \multicolumn{4}{|c|}{ Cx. quinquefasciatus Treated with $\mathrm{LC}_{25}$ of Propoxur } & \multicolumn{4}{|c|}{$C x$. quinquefasciatus Treated with $\mathrm{LC}_{50}$ of Propoxur } \\
\hline & $r\left(d^{-1}\right)$ & $\mathbf{R}_{0}$ & $T(d)$ & $\lambda\left(d^{-1}\right)$ & $r\left(d^{-1}\right)$ & $\mathbf{R}_{0}$ & $\mathrm{~T}(\mathrm{~d})$ & $\lambda\left(d^{-1}\right)$ \\
\hline F0 & $0.16 \pm 0.0043 \mathrm{a}$ & $29.52 \pm 2.61 \mathrm{a}$ & $20.76 \pm 0.00072 \mathrm{a}$ & $1.18 \pm 0.0056 \mathrm{a}$ & $0.16 \pm 0.043 \mathrm{a}$ & $29.52 \pm 2.61 \mathrm{a}$ & $20.76 \pm 0.00072 \mathrm{a}$ & $1.18 \pm 0.0051 \mathrm{a}$ \\
\hline F1 & $0.13 \pm 0.0055 b$ & $17.40 \pm 2.15 b$ & $22.62 \pm 0.00095 b$ & $1.13 \pm 0.0063 b$ & $0.10 \pm 0.0053 \mathrm{~b}$ & $14.59 \pm 1.95 b$ & $25.70 \pm 0.11 \mathrm{~b}$ & $1.11 \pm 0.0059 b$ \\
\hline F5 & $0.11 \pm 0.0058 \mathrm{~b}$ & $14.19 \pm 1.90 b$ & $23.28 \pm 0.00059 \mathrm{~b}$ & $1.12 \pm 0.0065 b$ & $0.10 \pm 0.0073 b$ & $10.86 \pm 1.81 \mathrm{~b}$ & $23.34 \pm 0.00081 \mathrm{~b}$ & $1.11 \pm 0.0081 \mathrm{~b}$ \\
\hline F10 & $0.10 \pm 0.0061 b$ & $12.27 \pm 1.81 \mathrm{~b}$ & $24.57 \pm 0.00013 b$ & $1.11 \pm 0.0068 b$ & $0.10 \pm 0.0073 b$ & $9.99 \pm 1.67 b$ & $23.40 \pm 0.0019 \mathrm{~b}$ & $1.10 \pm 0.0080 b$ \\
\hline F15 & $0.11 \pm 0.0065 b$ & $12.31 \pm 1.83 b$ & $23.40 \pm 0.0011 \mathrm{~b}$ & $1.11 \pm 0.0072 \mathrm{~b}$ & $0.10 \pm 0.0074 \mathrm{~b}$ & $9.85 \pm 1.81 \mathrm{~b}$ & $25.55 \pm 0.028 b$ & $1.09 \pm 0.0081 b$ \\
\hline
\end{tabular}

$\mathrm{r}$ : Intrinsic rate of increase, $\mathrm{R}_{0}$ : Net reproductive rate (offspring per individual), T: Mean generation time, $\lambda$ : Finite rate of increase. The values are given as mean \pm SE. a: No significant difference compared with F0 at the $p=0.05$ level. b: Significant difference compared with F0 at the $p=0.05$ level. 


\subsection{Analysis of the Possible Resistance Mechanism}

\subsubsection{Metabolic Enzyme Activity}

The activities of both esterase and cytochrome P450 monooxygenase (P450) in the selected generations displayed a slight increasing tendency compared with F0 (Figure 3). The former activity level varied from $2.20 \pm 0.50$ to $4.55 \pm 0.43 \mu \mathrm{mol} / \mathrm{min} / \mathrm{mg}$ protein in the strains selected by $\mathrm{LC}_{25}$ of propoxur and from $2.19 \pm 0.17$ to $3.54 \pm 0.39 \mu \mathrm{mol} / \mathrm{min} / \mathrm{mg}$ protein in the populations exposed to $\mathrm{LC}_{50}$ of propoxur (Figure 3). The latter activity level ranged from $0.52 \pm 0.05$ to $0.98 \pm 0.14 \mathrm{nmol} / \mathrm{min} / \mathrm{mg}$ protein in the strains selected by $\mathrm{LC}_{25}$ of propoxur and from $0.56 \pm 0.02$ to $0.82 \pm 0.11 \mathrm{nmol} / \mathrm{min} / \mathrm{mg}$ protein among the populations processed using $\mathrm{LC}_{50}$ of propoxur (Figure 3). However, the variation trend of the activities of glutathione $S$-transferase (GST) was irregular among the propoxur-sel populations of Cx. quinquefasciatus (Figure 3).
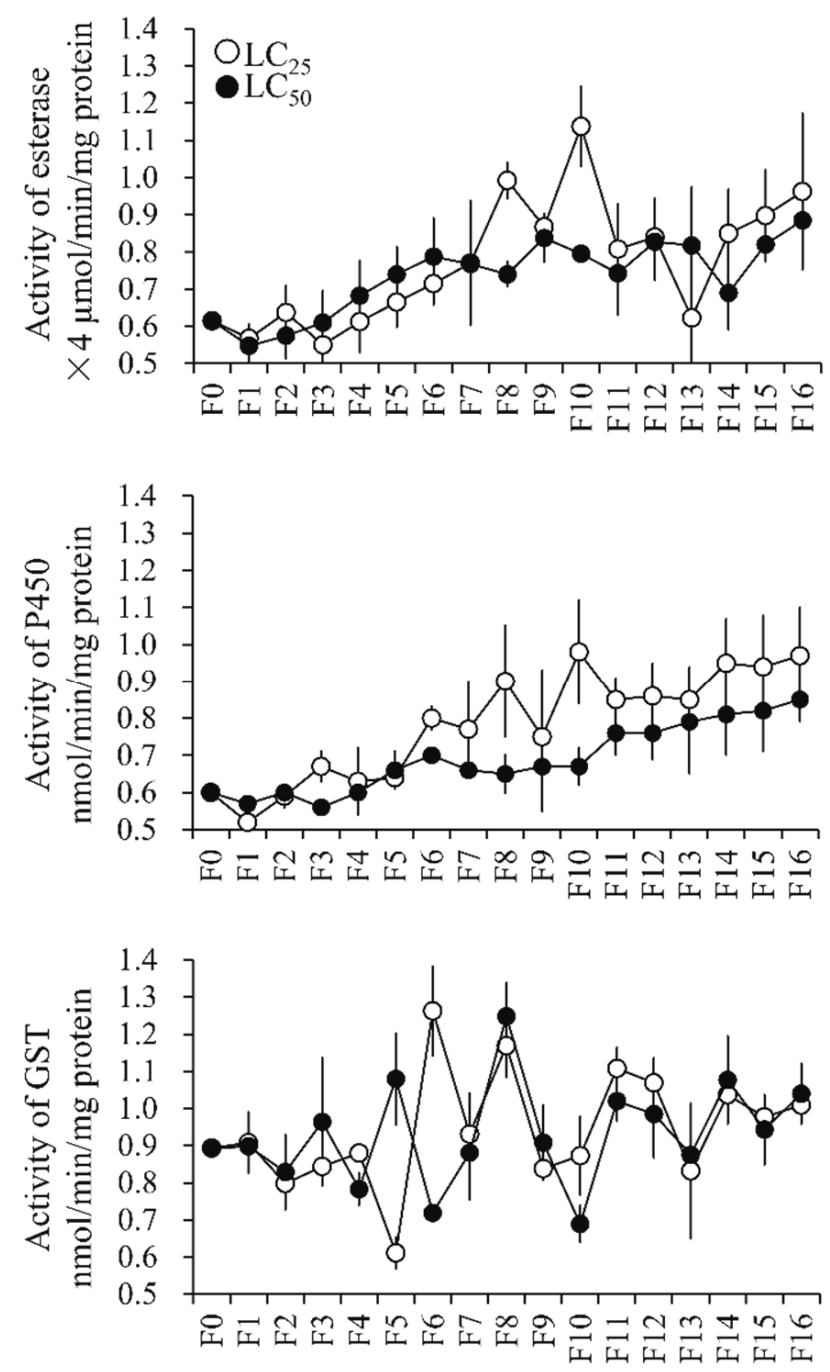

Figure 3. Activity of metabolic detoxifying enzymes in the populations exposed to $\mathrm{LC}_{25}$ and $\mathrm{LC}_{50}$ levels of propoxur. GST: glutathione S-transferase; P450: cytochrome P450 monooxygenase. 


\subsubsection{Transcription Levels of $P 450$ Genes in F0 Induced by Propoxur}

Significantly higher over-transcription levels of 18 and 16 of the 32 tested P450 genes were found to be induced by the $\mathrm{LC}_{25}$ and $\mathrm{LC}_{50}$ concentrations compared with the control, respectively, by significance analysis (Figure 4); the 14 genes cyp9j45, cyp4h40, cyp6ag12, cyp9al1, cyp6aa8, cyp4d42v1, cyp6bz2, cyp6aa7, cyp6z12, cyp9j33, cyp4c52v1, cyp6aa9, cyp4c38, and cyp9j43 displayed significant increases under both treatments (Figure 4).

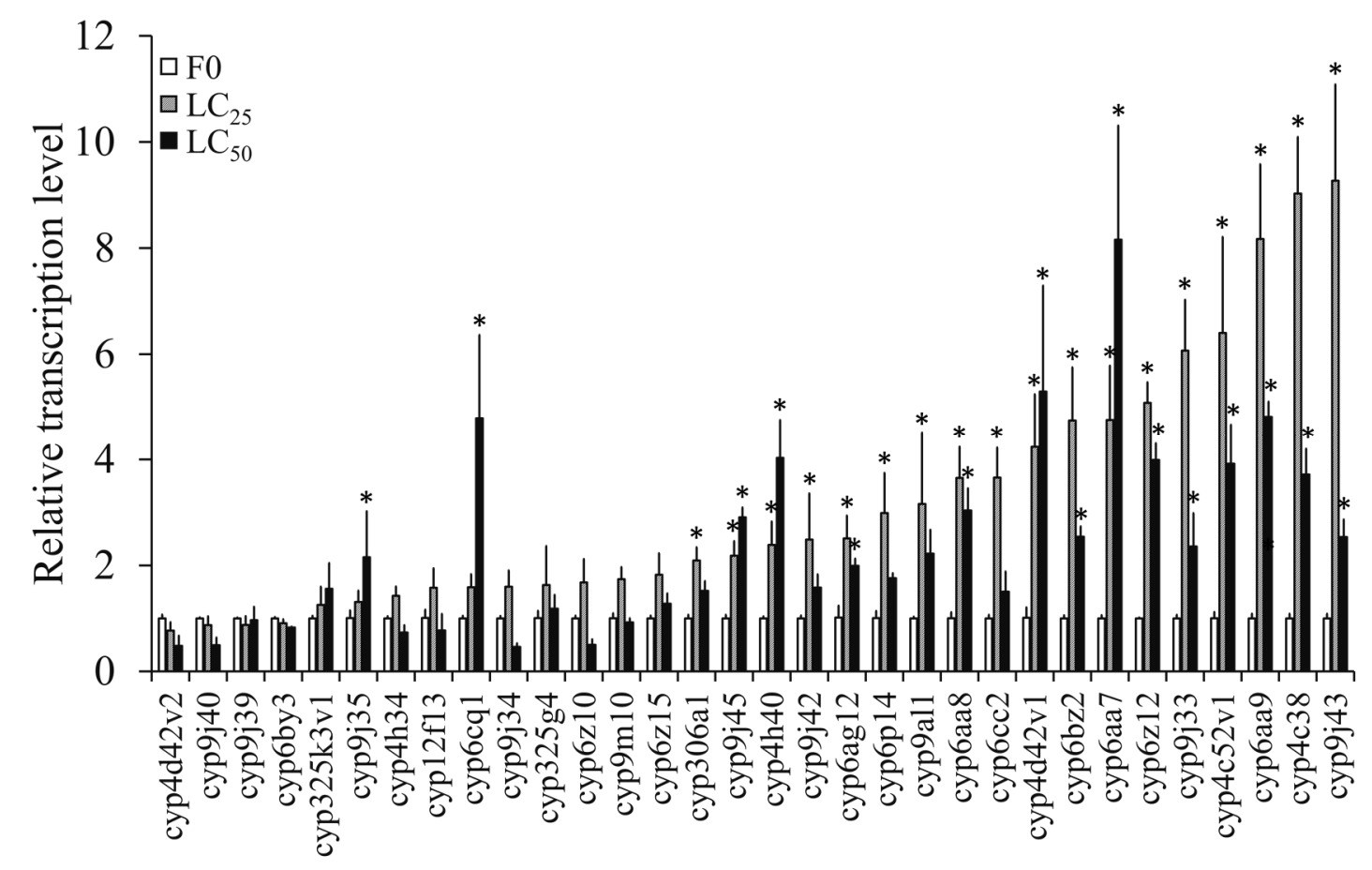

Figure 4. The induction of $\mathrm{P} 450$ gene transcription in $C x$. quinquefasciatus following $\mathrm{LC}_{25}$ and $\mathrm{LC}_{50}$ exposure to propoxur. The asterisks indicate genes significantly over-expressed compared with in F0 ( $\geq 2$ folds).

\subsubsection{Transcription Levels of P450 Genes in Propoxur-Sel Strains of F1, F5, F10, and F15}

In $\mathrm{F} 1$ of the strains selected by $\mathrm{LC}_{25}$ and $\mathrm{LC}_{50}$ levels of propoxur, four genes (cyp325g4, cyp6p14, cyp4d42v1, cyp4c52v1) and five genes (cyp12f13, cyp325g4, cyp9j45, cyp9j43, cyp6aa9), respectively, were significantly over-expressed compared with in the control (Figure 5). Further, the transcription levels of the four genes cyp325g4, cyp4d42v1, cyp4c52v1, and cyp6aa9 and the seven genes cyp9j35, cyp325g4, cyp9j45, cyp6p14, cyp4d42v1, cyp4c52v1, and cyp6aa9 in F5 of the strains selected by $\mathrm{LC}_{25}$ and $\mathrm{LC}_{50}$, respectively, were obviously higher (Figure 5). Moreover, the eight genes cyp9j35, cyp12f13, cyp325g4, cyp6p14, cyp4d42v1, cyp4c52v1, cyp9j43, and cyp6aa9 and the four genes cyp9j45, cyp4d42v1, cyp4c52v1, and cyp6aa9 in $\mathrm{F} 10$ of the strains selected by $\mathrm{LC}_{25}$ and $\mathrm{LC}_{50}$, respectively, were found to show significant over-transcription (Figure 5). Lastly, in F15 of the strains selected by $\mathrm{LC}_{25}$ and $\mathrm{LC}_{50}$ levels of propoxur, the expression levels of the eight genes cyp9j40, cyp325g4, cyp9j45, cyp6ag12, cyp9al1, cyp4d42v1, cyp4c52v1, and cyp6aa9 and the seven genes cyp325g4, cyp9j45, cyp9j42, cyp6p14, cyp4d42v1, cyp4c52v1, and cyp6aa9, respectively, were higher (Figure 5). 


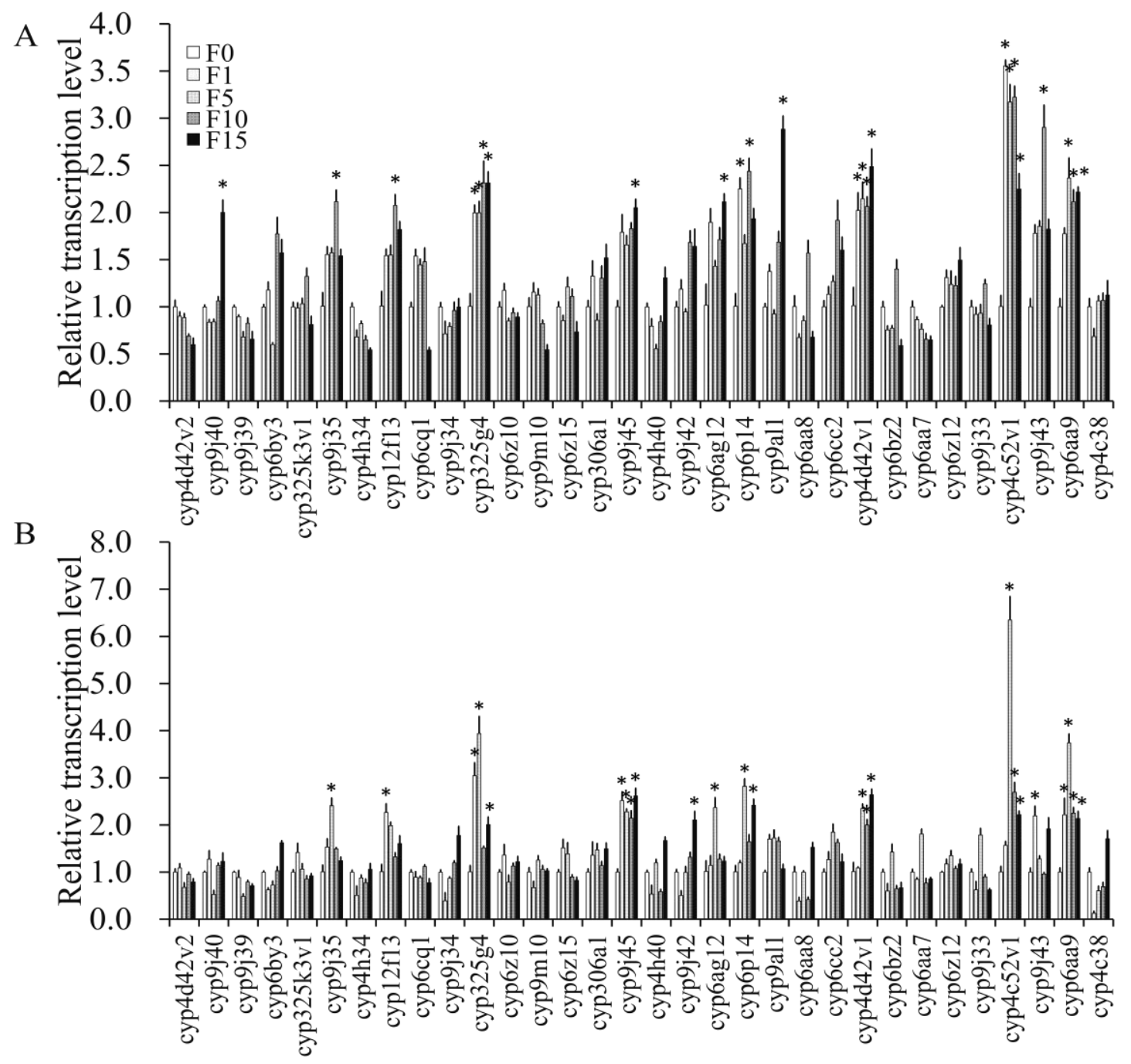

Figure 5. The relative transcription levels of P450 genes in F1, F5, F10, and F15 resistant strains of $C x$. quinquefasciatus selected by $\mathrm{LC}_{25}$ (A) and $\mathrm{LC}_{50}$ (B) exposure to propoxur. The asterisks indicate genes which were significantly over-expressed compared with in F0 ( $\geq 2$ folds).

The transcription levels of cyp4d42v1, cyp4c52v1, and cyp6aa9 were significantly increasingly transcribed in all three tested $C x$. quinquefasciatus generations (F5, F10, and F15) selected by either $\mathrm{LC}_{25}$ or $\mathrm{LC}_{50}$ treatments (Figure 5).

\section{Discussion}

The overreliance on either chemical or biological insecticides for mosquito control has shown the tendency to resistance and physiological alterations developing in mosquito populations [7-9]. Therefore, understanding the sublethal and lethal effects of insecticides could be crucial for decision-making in resistance and integrated pest management programs [37]. This study assessed the effects of propoxur, a widely used broad-spectrum carbamate insecticide, on $C x$. quinquefasciatus at the multigenerational level, including resistance development, metabolic mechanisms, and sublethal effects. The data provide a platform for understanding the potential relationship between the toxicity of a given product in laboratory assays and the exposure risk associated with resistance development under field conditions.

We observed that propoxur exposure at concentrations of $\mathrm{LC}_{25}$ and $\mathrm{LC}_{50}$ for 16 generations led to low-level resistance ( $<10$-fold) in $C x$. quinquefasciatus, which corresponds to previous studies in which it was found that the resistance ratios of $C x$. pipiens pallens could rise up to 2.5- and 7.9-fold after 8 
and 16 generations of propoxur selection, respectively [38,39]. Interestingly, the lower concentration $\left(\mathrm{LC}_{25}\right)$ could lead to higher resistance from F10 to F16 when compared with the higher one (LC 50$)$ (Figure 1). One possible reason for this could be that a low dose could induce multifactorial resistance development at a relatively slow speed, while a high dose could promote evolution of the major resistant gene(s) rapidly. Previous studies showed that the propoxur-resistant strain of $C x$. pipiens pallens was cross-resistant to DDVP (dichlorvos) and cypermethrin $[40,41]$ but not resistant to DDT, deltamethrin, and acetofenate [42-45]. Nevertheless, the propoxur-sels displayed cross-resistance to neither deltamethrin nor others like etofenprox, nitenpyram, abamectin, chlorpyrifos, and spinetoram in this study (Figure 2). This indicated that these insecticides could be used in rotation with propoxur in the management of insecticide resistance.

Resistance development as a result of AChE structural modification has been broadly documented in many insects, including several mosquito species. For instance, Zhao et al. (2014) in their study associated the A328S, V185M, and G247S mutations with propoxur resistance in Cx. quinquefasciatus [25]. In our current study, no mutation was detected in ace-1 of the propoxur-sel strains (data not shown), which indicated that the propoxur-sels might have developed some other defense mechanism(s). Currently, many studies have shown cytochrome P450 monooxygenase to play an important role in the detoxifying strategies of sanitary pests against propoxur $[46,47]$. For example, it was reported that propoxur resistance in German cockroach populations was associated with increased activity of cytochrome P450 monooxygenase [46]. In another study, both P450 monooxygenase and esterase were involved in propoxur resistance in field populations of German cockroaches in Singapore [47]. Indeed, enhanced activities of cytochrome P450 monooxygenase and esterase were observed in propoxur-sel strains in this study, indicating that a detoxification mechanism might be responsible for resistance development in Cx. quinquefasciatus (Figure 3). In a previous study, the overexpression of the P450 gene cyp $9 m 10$ was suggested to be responsible for permethrin resistance in two isogenic strains of $C x$. quinquefasciatus (i.e., ISOP450 and ISOJPAL), and eight polymorphic sites of the resistant alleles were found to be different from the susceptible ones [48]. Further, some other P450 genes were also found to be induced (overexpressed) by permethrin in $C x$. quinquefasciatus, with different sets involved in different resistant strains (e.g., cyp325k3v1, cyp4d42v2, cyp9j45, (cyp) CPIJ000926, cyp325g4, cyp4c38, and cyp4h40 in the HAmCqG8 strain, and cyp9m10, cyp6z12, cyp9j33, cyp9j43, cyp9j34, cyp306a1, cyp6z15, cyp9j45, cyp9al1, cyp4c52v1, and cyp9j39 in the MAmCqG6 strain) [29]. In field populations of $C x$. pipiens pallens Coquillett and Cx. quinquefasciatus, five up-regulated genes of P450 (cyp345p1, cyp358b1, cyp $4 f d 2, c y p 4 c d 2$, and cyp6jn1) were found to be associated with propoxur resistance in Cx. pallens and $C x$. quinquefasciatus [49]. Since previous studies indicated that most of the P450 genes associated with insecticide resistance belong to the cyp4 and cyp6 clades $[29,49,50]$, we selected 32 P450 genes belonging to these clades for analysis. The data showed that induction by different doses of propoxur and constitutive expression in different generations of propoxur-sel strains resulted in inconsistent identification of the P450 genes probably related with resistance, although the three genes cyp $4 d 42 v 1$, cyp4c52v1, and cyp6aa9 displayed a coincidence to some degree in different treatments (Figures 4 and 5). This indicated that the pathway of metabolic detoxification involving cytochrome P450 monooxygenase in mosquito is rather complicated.

Sublethal and lethal effects of insecticides can not only induce direct mortality and promote development of resistance but may also have effects on the development, survival, and reproduction of the target insect [8,15]. This phenomenon has been reported in mosquito and other pests. A study on Anopheles stephensi Liston observed that sublethal exposure to propoxur resulted in decrements in fecundity, egg hatchability, and F/M sex ratio but also in prolonged larval duration and adult longevity [14]. In another study, A. aegypti and A. albopictus exposed to propoxur were also found to live longer and with a heightened fertility level compared with the control [51]. Similarly, this study also showed that the fecundity, longevity, sex ratio $(\mathrm{F} / \mathrm{M})$, and hatchability of the adult survivors of propoxur-exposed $C x$. quinquefasciatus were decreased compared with those of the untreated counterpart (F0). The sublethal effects on physiology and the decrease in fecundity induced by 
propoxur exposure have also been reported in other insects, including Musca domestica and German cockroach (Blattela germanica). In Musca domestica, a decrease in fecundity on propoxur exposure was discovered [52]. The oothecae could fall off before maturity in Blattela germanica, and delayed hatching was observed in the ones that retained the oothecae [53]. When the oothecae were treated with propoxur, the hatching and nymph survival rates were also reduced [53]. Similar physiological defects were also observed in $C x$. quinquefasciatus with malathion and in An. quadrimaculatus with aldrin, chlordane, DDT, BHC (benzene hexachloride), and rotenone [37,54]. These sublethal effects occurred probably because coping with the toxicity of insecticides could be dire and could require energy and resource allocation for adaptation and survival. The demographic parameters (r, Ro, $T$, and $\lambda$ ) and sex ratio of the $C x$. quinquefasciatus offspring also showed a significant difference compared to F0. In a previous report, significant sex ratio distortion was only found to occur in the parental generation [37]. However, this study showed a significant sex ratio distortion not only in the parental generation but also in the progeny of $C x$. quinquefasciatus, which might have occurred through vertical transfer of propoxur from the mother to the offspring.

\section{Conclusions}

In general, when exposed to sublethal and lethal doses of propoxur, $C x$. quinquefasciatus could develop resistance via physiological adaption. The application of this insecticide could lead to a decline of the population not only by killing susceptible ones but also by reducing the reproductive potential among the resistant strains and, finally, impacting the population density of mosquito communities. Thus, this study provides a reference for the rational application of propoxur for mosquito control in the field.

Author Contributions: X.H. and Z.Y. conceived and designed the research. X.Z. and Q.C. conducted experiments. X.Z., X.H. and S.K. analyzed the data and wrote the manuscript. All the authors read, corrected, and approved the manuscript.

Funding: This research was supported by National Key R\&D Program of China (2018ZX10101004 and 2017YFD0200400), the External Cooperation Program of CAS (153211KYSB20160001), and National Science and Technology Major Project of 13th Five-Year Plan, China (2017ZX10303404).

Acknowledgments: We are thankful to Jianhong Li (Huazhong Agricultural University) for kindly providing insecticides.

Conflicts of Interest: The authors declare no conflict of interest.

\section{References}

1. Guo, X.X.; Li, C.X.X.; Deng, Y.Q.; Xing, D.; Liu, Q.M.; Wu, Q.; Sun, A.J.; Dong, Y.D.; Cao, W.C.; Qin, C.F.; et al. Culex pipiens quinquefasciatus: A potential vector to transmit Zika virus. Emerg. Microbes Infect. 2016, 5, e102. [CrossRef] [PubMed]

2. Guedes, D.R.D.; Paiva, M.H.S.; Donato, M.M.A.; Barbosa, P.P.; Krokovsky, L.; Rocha, S.W.; Saraiva, K.L.A.; Crespo, M.M.; Barbosa, R.M.R.; Oliveira, C.M.F.; et al. Zika virus replication in the mosquito Culex quinquefasciatus in Brazil. Emerg. Microbes Infect. 2017, 6, e69. [CrossRef] [PubMed]

3. Martins, W.F.S.; Subramaniam, K.; Steen, K.; Mawejje, H.; Liloglou, T.; Donnelly, M.J.; Wilding, C.S. Detection and quantitation of copy number variation in the voltage-gated sodium channel gene of the mosquito Culex quinquefasciatus. Sci. Rep. 2017, 7, 5821. [CrossRef] [PubMed]

4. Redekop, W.K.; Lenk, E.J.; Luyendijk, M.; Fitzpatrick, C.; Niessen, L.; Stolk, W.A.; Tediosi, F.; Rijnsburger, A.J.; Bakker, R.; Hontelez, J.A.C.; et al. The socioeconomic benefit to individuals of achieving the 2020 targets for five preventive chemotherapy neglected tropical diseases. PLoS Negl. Trop. Dis. 2017, 11, e0005289. [CrossRef] [PubMed]

5. Reid, W.R.; Zhang, L.; Gong, Y.H.; Li, T.; Liu, N.N. Gene expression profiles of the southern house mosquito Culex quinquefasciatus during exposure to permethrin. Insect Sci. 2018, 3, 439-453. [CrossRef] [PubMed]

6. Guo, Q.; Cai, Q.; Yan, J.; Hu, X.; Zheng, D.; Yuan, Z. Single nucleotide deletion of cqm1 gene results in the development of resistance to Bacillus sphaericus in Culex quinquefasciatus. J. Insect Physiol. 2013, 59, 967-973. [CrossRef] [PubMed] 
7. Liu, N. Insecticide resistance in mosquitoes: Impact, mechanisms, and research directions. Annu. Rev. Entomol. 2015, 60, 537-559. [CrossRef] [PubMed]

8. Yu, S.S.; Ji, C.; Zhu, X.B.; Xue, J.W.; Wang, L.H.; Wang, Y. Impact of Bacillus sphaericus exposure on Anopheles dirus's fecundity and resistance development. Parasitol. Res. 2017, 116, 859-864. [CrossRef]

9. Cui, F.; Raymond, M.; Qiao, C.L. Insecticide resistance in vector mosquitoes in China. Pest Manag. Sci. 2006, 62, 1013-1022. [CrossRef]

10. Liang, P.; Tian, Y.A.; Biondi, A.; Desneux, N.; Gao, X.W. Short-term and transgenerational effects of the neonicotinoid nitenpyram on susceptibility to insecticides in two whitefly species. Ecotoxicology 2012, 21, 1889-1898. [CrossRef]

11. Mattah, P.A.D.; Futagbi, G.; Amekudzi, L.K.; Mattah, M.M.; Souz, D.K.; Kartey-Attipoe, W.D.; Bimi, L.; Wilson, M.D. Diversity in breeding sites and distribution of Anopheles mosquitoes in selected urban areas of southern Ghana. Parasit. Vectors 2017, 10, 25. [CrossRef] [PubMed]

12. Kibuthu, T.W.; Njenga, S.M.; Mbugua, A.K.; Muturi, E.J. Agricultural chemicals: Life changer for mosquito vectors in agricultural landscapes. Parasit. Vectors 2016, 9, 500. [CrossRef] [PubMed]

13. Buhagiar, T.S.; Devine, G.J.; Ritchie, S.A. Effects of sublethal exposure to metofluthrin on the fitness of Aedes aegypti in a domestic setting in Cairns, Queensland. Parasit. Vectors 2017, 10, 274. [CrossRef] [PubMed]

14. Sanil, D.; Shetty, N.J. The effect of sublethal exposure to temephos and propoxur on reproductive fitness and its influence on circadian rhythms of pupation and adult emergence in Anopheles stephensi Liston-A malaria vector. Parasitol. Res. 2012, 111, 423-432. [CrossRef] [PubMed]

15. Desneux, N.; Decourtye, A.; Delpuech, J.M. The sublethal effects of pesticides on beneficial arthropods. Annu. Rev. Entomol. 2007, 52, 81-106. [CrossRef]

16. Suwansirisilp, K.; Visetson, S.; Prabaripai, A.; Tanasinchayakul, S.; Grieco, J.P.; Bangs, M.J.; Chareonviriyaphap, T. Behavioral responses of Aedes aegypti and Culex quinquefasciatus (Diptera: Culicidae) to four essential oils in Thailand. J. Pest Sci. 2013, 86, 309-320. [CrossRef]

17. Heckel, D.G. Insecticide resistance after Silent Spring. Science 2012, 337, 1612-1614. [CrossRef]

18. Seth, V.; Banerjee, B.D.; Bhattacharya, A.; Chakravorty, A.K. Lipid peroxidation, antioxidant enzymes, and glutathione redox system in blood of human poisoning with propoxur. Clin. Biochem. 2000, 33, 683-685. [CrossRef]

19. Pennington, M.J.; Prager, S.M.; Walton, W.E.; Trumble, T.M. Culex quinquefasciatus larval microbiomes vary with instar and exposure to common wastewater contaminants. Sci. Rep. 2016, 6, 21969. [CrossRef]

20. Almeida, L.G.; Moraes, L.A.B.; Trigo, J.R.; Omoto, C.; Cônsoli, F.L. The gut microbiota of insecticide-resistant insects houses insecticide degrading bacteria: A potential source for biotechnological exploitation. PLOS ONE 2017, 12, e0174754. [CrossRef]

21. Jiang, Y.; Swale, D.; Carlier, P.R.; Hartsel, J.A.; Ma, M.; Ekström, F.; Bloomquist, J.R. Evaluation of novel carbamate insecticides for neurotoxicity to non-target species. PestiCx. Biochem. Physiol. 2013, 106, 156-161. [CrossRef]

22. Baron, R.L. Carbamate Insecticides. In Handbook Pesticide Toxicology; Hayes, W.J., Laws, E.R., Eds.; Academic Press: New York, NY, USA, 1991; Volume 3: Classes of Pesticides, pp. 1125-1189.

23. Eraslan, G.; Kanbur, M.; Silici, S.; Liman, B.C.; Altınordulu, S.; Sarıca, Z. Evaluation of protective effect of bee pollen against propoxur toxicity in rat. Ecotoxicol. Environ. Saf. 2009, 72, 931-937. [CrossRef] [PubMed]

24. Mahalakshmi, M.; Priya, S.V.; Arabindoo, B.; Palanichamy, M.; Murugesan, V. Photocatalytic degradation of aqueous propoxur solution using $\mathrm{TiO} 2$ and $\mathrm{H} \beta$ zeolite-supported TiO2. J. Hazard. Mater. 2009, 161, 336-343. [CrossRef] [PubMed]

25. Zhao, M.; Dong, Y.; Ran, X.; Wu, Z.; Guo, X.; Zhang, Y.; Xing, D.; Yan, T.; Wang, G.; Zhu, X.; et al. Point mutations associated with organophosphate and carbamate resistance in chinese strains of Culex pipiens quinquefasciatus (Diptera: Culicidae). PLoS ONE 2014, 9, e95260. [CrossRef] [PubMed]

26. Han, Y.C.; Yu, W.T.; Zhang, W.Q.; Yang, Y.H.; Walsh, T.; Oakeshott, J.G.; Wu, Y.D. Variation in P450-mediated fenvalerate resistance levels is not correlated with CYP337B3 genotype in Chinese populations of Helicoverpa armigera. Pestic. Biochem. Physiol. 2015, 121, 129-135. [CrossRef] [PubMed]

27. Zhang, X.L.; Liao, X.; Miao, K.K.; Zhang, K.X.; Wan, H.; Li, J.H. Insecticide resistance monitoring and correlation analysis of insecticides in field populations of the brown planthopper Nilaparvata lugens (Stål). Pestic. Biochem. Physiol. 2016, 132, 13-20. [CrossRef] [PubMed] 
28. Liu, N.; Li, T.; Reid, W.R.; Yang, T.; Zhang, L. Multiple cytochrome P450 genes: Their constitutive overexpression and permethrin induction in insecticide resistant mosquitoes, Culex quinquefasciatus. PLOS ONE 2011, 6, e23403. [CrossRef]

29. Gong, Y.; Li, T.; Zhang, L.; Gao, X.; Liu, N. Permethrin induction of multiple cytochrome P450 genes in insecticide resistant mosquitoes, Culex quinquefasciatus. Int. J. Biol. Sci. 2013, 9, 863-871. [CrossRef]

30. Li, T.; Liu, N. Regulation of P450-mediated permethrin resistance in Culex quinquefasciatus by the GPCR/G $\alpha$ s/AC/cAMP/PKA signaling cascade. Biochem. Biophys. Rep. 2017, 12, 12-19. [CrossRef]

31. Livak, K.L.; Schmittgen, T.D. Analysis of relative gene expression data using realtime quantitative PCR and the $2^{-\Delta \Delta C T}$ method. Methods 2001, 25, 402-408. [CrossRef]

32. Chi, H.; Liu, H. Two new methods for the study of insect population ecology. Bull. Inst. Zool. Acad. Sin. 1985, 24, 225-240.

33. Chi, H. Life-table analysis incorporating both sexes and variable development rate among individuals. Environ. Entomol. 1988, 17, 26-34. [CrossRef]

34. TWOSEX-MSChart. Available online: http://140.120.197.173/Ecology/prod02.htm (accessed on 1 July 2019).

35. Efron, B.; Tibshirani, R.J. An Introduction to the Bootstrap; Chapman and Hall: London, UK, 1993; pp. 49-54.

36. Akköprü, P.E.; Atlihan, R.; Okut, H.; Chi, H. Demographic assessment of plant cultivar resistance to insect pests: A case study of the dusky-veined walnut aphid (Hemiptera: Callaphididae) on five walnut cultivars. J. Econ. Entomol. 2015, 108, 378-387. [CrossRef] [PubMed]

37. Robert, L.L.; Olson, J.K. Effects of sublethal dosages of insecticides on Culex quinquefasciatus. J. Am. Mosq. Control. Assoc. 1989, 5, 239-246. [PubMed]

38. Li, C.; Dong, Y.; Zhao, T. Relationship of esterase, acetylcholinesterase and propoxur-resistance to Culex pipiens pallens. Chin. J. Vector Bio. Control 2007, 18, 9-11.

39. Jiang, H.; Zhen, T.; Wang, H.; Cheng, P.; Sun, C.; Wang, H.; Wang, X.; Zhao, Y. Selection for resistance to propoxur in Culex pipiens pallens and its cross-resistance. Chin. J. Vector Biol. Control 2005, 16, 185-186.

40. Kou, J.X.; Liu, H.M.; Gong, M.Q. Resistance levels and cross-resistance of Culex pipiens pallens to commonly used chemical pesticides after long-term breeding. Parasitosis Infect. Dis. 2013, 11, 176-179.

41. Jiang, B.; Li, S.G.; Quan, X.; Xue, Q.J.; Tan, W.B.; Liu, Y.C.X.; Wang, X.G.; Wang, H.W. Experimental study on cross-resistance of Culex pipiens pallens to 3 kinds of chemical pesticides. Chin. J. Schisto Control 2014, 26, 531-533.

42. Wang, X.; Zhen, T.; Liu, F.; Li, S.; Wang, H.; Zhao, Y.; Sun, C. Cross-resistance of resistant strain of Culex pipiens pallens to chemical insecticides. Chin. J. Vector Biol. Control 1999, 10, 18-20.

43. Du, Q. Resistance development and cross-resistance of propoxur-resistant Culex Pipiens Pallens and DDVP-resistant Culex Pipiens Pallens. China Trop. Med. 2009, 9, 799-800.

44. Li, S. The cross -resistance of three resistant strains of Culex pipiens pallens to the five pesticides. China Trop. Med. 2009, 9, 803-804.

45. Zhang, C.; Li, X.; Dai, W.; Xu, Q.; Zhen, T. Development of resistance of propoxur selected Culex pipiens pallens. China Trop. Med. 2005, 5, 1173-1174.

46. Valles, S.M.; Yu, S.J. Detection and biochemical characterization of insecticide resistance in the German Cockroach (Dictyoptera: Blattellidae). J. Econ. Entomol. 1996, 89, 21-26. [CrossRef]

47. Chai, R.Y; Lee, C.Y. Insecticide resistance profiles and synergism in field populations of the German Cockroach (Dictyoptera: Blattellidae) from Singapore. J. Econ. Entomol. 2010, 103, 460-471. [CrossRef] [PubMed]

48. Hardstone, M.C.; Huang, X.; Harrington, L.C.; Scott, J.G. Differences in development, glycogen, and lipid content associated with cytochrome $\mathrm{P} 450$-mediated permethrin resistance in Culex pipiens quinquefasciatus (Diptera: Culicidae). J. Med. Entomol. 2010, 47, 188-198. [CrossRef] [PubMed]

49. Li, C.X.; Guo, X.X.; Zhang, Y.M.; Dong, Y.D.; Xing, D.; Yan, T.; Wang, G.; Zhang, H.D.; Zhao, T.Y. Identification of genes involved in pyrethroid-, propoxur-, and dichlorvos- insecticides resistance in the mosquitoes, Culex pipiens complex (Diptera: Culicidae). Acta Tropica 2016, 157, 84-95. [CrossRef] [PubMed]

50. Zhuang, H.M.; Wang, K.F.; Zheng, L.; Wu, Z.J.; Miyata, T.; Wu, G. Identification and characterization of a cytochrome P450 CYP6CX1 putatively associated with insecticide resistance in Bemisia tabaci. Insect Sci. 2011, 18, 484-494. [CrossRef] 
51. Wahyuningsih, N.E.; Nurussakinah, F.; Siswoyowati. Ae. aegypti and Ae. albopictus mosquito longevity is longer as impact of exposure to propoxur aerosol insecticide. In Planning for Environmental Sustainability for the Well-Being of Future Humanity, Proceedings of the 1ST UMM International Conference on Pure and Applied Research (UMM-ICOPAR 2015), Malang, East Java, Indonesia, 21-22 August 2015; Admin Conference UMM: Malang, East Java, Indonesia, 2015; pp. 125-131.

52. Georghiou, G.P. Effects of carbamates on house fly fecundity, longevity and food intake. J. Econ. Entomol. 1965, 58, 58-62. [CrossRef]

53. Harmon, J.D.; Ross, M.H. Effects of propoxur exposure on females of the German cockroach, Blattela germanica and their oothecae. Entomol. Exp. Appl. 2011, 44, 269-275. [CrossRef]

54. Lee, C.Y. Sublethal effects of insecticides on longevity, fecundity, and behavior of insect pests: A review. J. Biosci. 2000, 11, 107-112.

(C) 2019 by the authors. Licensee MDPI, Basel, Switzerland. This article is an open access article distributed under the terms and conditions of the Creative Commons Attribution (CC BY) license (http://creativecommons.org/licenses/by/4.0/). 